\title{
Letting Lilliputians Sit at The Table: Providing Physicians With a Magnified Voice to Counter the BROBDINGNAGIAN HMO
}

\author{
Brandt R. Voight \\ TABLE OF CONTENTS
}

I. INTRODUCTION

II. SETTING THE STAGE FOR A BROBDINGNAG-LIKE HMO

SOCIETY.

A. The Sherman Act and National Labor Relations Act Identify an "Employee's" Right to Bargain Collectively with the Corporate Employer.

B. Physicians Do Not Qualify as Employees under the National Labor Relations Act

III. INTRODUCING THE BROBDINGNAG-HMO TO THE LILLIPUTIANPHYSICIAN

A. Creating an Imbalance in Power Between the Brobdingnag-HMOs and Lilliputian-Physicians

B. Is HMO Consolidation Operationally Effective or Monopolistically Substandard?

C. Double Standards in Evaluating HMO and Physician Antitrust Violations

D. The Plight of the Powerless Physician Amidst the HMO's Monopolistic Authority.

IV. UNIFYING LILLIPUTIAN-LIKE PHYSICIANS AND RESTRAINING BROBDINGNAG-LIKE HMOS

A. An Overview of Legislative Solutions Attempted by States.......448

B. Congress' Attempted Solution: The Quality Health Care Coalition Act ...

1. History of the Quality Act .....................................................448

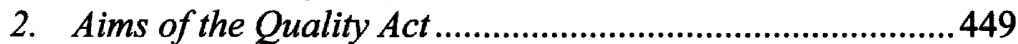

C. State Antitrust Exemptions for Lilliputian-like Physicians ........450

1. Specific State Legislative Enactments

2. Preemption Problems in Granting Physicians Antitrust Exemption Status

* J.D., 2007, Indiana University School of Law, Indianapolis, Indiana; B.S., 2004, Butler University, Indianapolis, Indiana. I would like to thank Sarah Fuhrman for her creativity and suggestion in using the light-hearted familiar English reference of Gulliver's Travels as a unifying theme for such a long-winded and complicated subject. The reoccurring theme provides an illustration for the theory and brings to life the many words used to explain this lengthy discussion. 
3. Avoiding Preemption Problems and Ensuring Antitrust Exemption Status for Physicians by Satisfying the State Action Doctrine.

D. AWP Statutes as a Popular Alternative Solution to Empowering Lilliputian-like Physicians...

1. AWP Statutes Defined.....

2. The McCarran-Ferguson Exception 453

3. AWP Statutes Prove to be an Inadequate Solution to Empowering Physicians.

V. DWARFING THE BROBDINGNAG AND MAGNIFYING THE VOICE OF THE LILLIPUTIAN.

A. Proposed Legislation to Enlarge the Influence of the Lilliputian-like Physicians and Counterbalance the Giant Power of Geographically Dominant HMOs 455

B. A Recent NLRB Decision Laid the Foundation for Granting Physicians the Authority to Bargain Collectively in Specific Circumstances

C. Identifying the Specific Circumstances that would Authorize Lilliputian-like Physicians to Bargain Collectively with Dominant HMOs

D. Learning from the Mistakes of Prior Legislative Attempts and Effectively Crafting the Proposed Legislation.

1. Ensuring Adequate State Oversight and Satisfaction of the State Action Doctrine.

2. Focus on Collective Bargaining, not Arbitration ..............461

3. Require Good Faith Bargaining from HMOs. 462

E. Predicted Impacts from Implementing the Proposed Legislation.

1. Increased Competition and Justice for Physicians through a Balanced Playing Field.

2. The Impact on Health Care Costs and Subsequent Economic Consequences 


\section{INTRODUCTION}

The fictional accounts of an eighteenth century English physician tell the story of an encounter with a population of Brobdingnags who use their size and sheer dominance to dictate and control their world. ${ }^{1}$ Large in both size and influence, these giant human-like creatures have complete authority over Lemuel Gulliver and his movements, considering him nothing more than a source of amusement and a second-thought. ${ }^{2}$ Forced to endure the unenjoyable experience of being subject to the whims of the Brobdingnags, Gulliver is even more disturbed to learn that their physical size is only minor in comparison to their ignorance. ${ }^{3}$ The King has no knowledge of politics, their lifestyles are primitive, and their dimwitted nature restricts progress. ${ }^{4}$ Their authority relies solely on their comparatively gigantic size. ${ }^{5}$

These accounts of Gulliver's Travels parallel and illustrate the reality of the present state of managed health care organizations in America. The nature of today's Health Management Organizations ("HMOs") place individual physicians in a Gulliver-like position, vulnerable to and unprotected from the whims of Brobdingnagian corporate powerhouses. Not only are physicians outmatched in size but also in strength. Robbed of any ability to effectively negotiate with dominant HMOs, the small influence of physicians barely merits more than a second-thought by the HMOs. As a result, both physicians and patients are subjected to a flawed system that is only magnified due to the unchecked power and size of the giant HMO.

Part II of this Note will begin by considering the history of employees' rights to collectively bargain with employers as compared with the absence of physicians' rights to collectively bargain with HMOs. Part III will examine the changing landscape of health care caused by the introduction of HMOs in the United States. Part IV will explore what solutions have been attempted thus far by various states, physicians, and the federal government, as well as how those attempts have fared. Finally, in Part V, this Note will propose and consider the impact of a specific solution that properly extends physicians' legal rights wherever a Brobdingnagian society is found. Not all HMO structures are bad. Indeed, the financial structures they implement often lead to the containment of high costs and promote a more efficient provision of health care. Where a single HMO or two dominate an entire area, however, the financial aims of the

1 JONATHAN SWIFT, TRAVELS INTO SEVERAL REMOTE NATIONS OF THE WORLD BY LEMUEL GULLIVER pt. II (Lee Jaffe ed., Harrison \& Co. 2000) (1735), available at http://www.jaffebros.$\mathrm{com} /$ lee/gulliver/contents.html. This novel tells the story of Gulliver who discovers a remote island only to find a population of giant, human-like creatures called Brobdingnags, who exert their size and hold him captive as their servant.

$\begin{array}{ll}{ }_{2}^{2} & I d . \\ { }_{3}^{3} & I d . \\ { }_{4} & I d . \\ { }_{5}^{5} & I d .\end{array}$ 
HMO can begin to overtake concerns about the quality of health care provided and the rights of physicians to autonomously conduct their practices as they deem necessary. Such a society exists in geographic locations where HMOs exhibit a monopolistic authority over the smaller, individually-weak physicians of the region. It is this dominant, Brobdingnag-like nature that makes the HMOs and their influence dangerous not only to the health care industry but also particularly to the smaller, more vulnerable physicians. It is in the HMOdominated worlds that legislation is needed to empower physicians and counterbalance the abusive power enjoyed by the giant HMOs.

\section{SETTING THE STAGE FOR A BROBDINGNAG-LIKE HMO SOCIETY}

\section{A. The Sherman Act and National Labor Relations Act Identify an "Employee's" Right to Bargain Collectively with the Corporate Employer}

Historically, the United States has favored a free market system that encourages competition and attempts to prevent large, powerhouse monopolies from dictating an industry and constraining consumer choice. In an attempt to avoid large monopolistic giants that dominate and puppeteer their industry, as Brobdingnags dictated their world, and constrain competition and consumer choice, Congress passed the Sherman Act of 1890. Section 2 of the Sherman Act establishes monopolies of commercial trade as a felony. ${ }^{6}$ Specifically, it states:

Every person who shall monopolize, or attempt to monopolize, or combine or conspire with any other person or persons, to monopolize any part of the trade or commerce among the several States, or with foreign nations, shall be deemed guilty of a felony, and, on conviction thereof, shall be punished by fine not exceeding $\$ 100,000,000$ if a corporation, or, if any other person, $\$ 1,000,000$, or by imprisonment not exceeding 10 years ...7

Furthermore, for the sake of justice and deterrence, the court is also granted the discretion to impose both a fine and imprisonment on an offender convicted of the felony. ${ }^{8}$

At that time it was believed by society that a certain inequality of bargaining power existed between employees and their employers. ${ }^{9}$ In addressing this

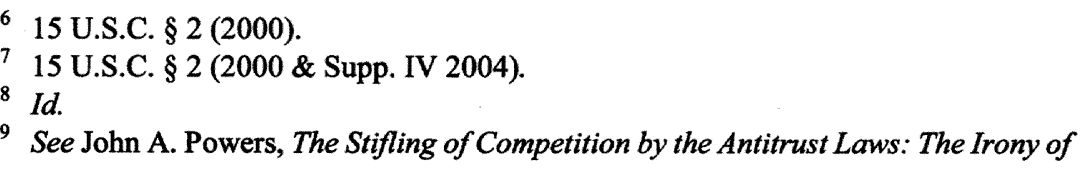


inequity, Congress passed the Clayton Antitrust Act of 1914 to provide labor employees with an outlet to voice their demands. ${ }^{10}$ The Clayton Act exempts labor unions from antitrust and monopoly law by allowing unions to collectively bargain on behalf of their members. ${ }^{11}$ The reason the Clayton Act can coexist with the Sherman Act, which prohibits employment collective bargaining, is because the Clayton Act removes "human labor" from the "commodity or article of commerce" category and, therefore, removes "human labor" from the realm of Sherman Act regulation. ${ }^{12}$ This labor exception permitting collective bargaining under the Clayton Act was also made a part of the National Labor Relations Act ("NLRA"), which also formed the National Labor Relations Board ("NLRB") to adjudicate federal labor disputes. ${ }^{13}$

The NLRA specifically defined the "human labor" exception by stating that "[e]mployees shall have the right to self-organization, to form, join, or assist labor organizations, to bargain collectively through representatives of their own choosing, and to engage in other concerted activities for the purpose of collective bargaining or other mutual aid or protection ...."14 Similar to the original intentions of Congress in passing the Clayton Act, the purpose of the NLRA definition and antitrust exemption was to "promote industrial peace and stability" by ensuring that all parties are treated fairly. ${ }^{15}$ Fulfilling its purpose, blue collar workers began utilizing collective bargaining to voice their demands and "level the playing field" between themselves and their employers by forming labor unions and collective bargaining units. ${ }^{16}$

\section{B. Physicians Do Not Qualify as Employees under the National Labor Relations Act}

Despite such progress in the arena of labor employees, physicians who are deemed to be "[i]ndependent, self-employed, or non-salaried" do not fall under the employee antitrust exemption established in the NLRA, are discriminatorily branded as professional employees or independent contractors, and are prevented from collective bargaining. ${ }^{17}$ In defining "employee", the NLRA specifically excepts certain persons, stating that the term "employee ... shall not include any individual employed as an agricultural laborer, or in the domestic

the Health Care Industry, 15 J.L. \& HEALTH 223, 232 (2000) (discussing how the National Labor Relations Act was enacted to fix this problem).

1015 U.S.C. $\$ 17(2000)$.

11 Id.

12 Id.; see also Ellen L. Luepke, White Coat, Blue Collar: Physician Unionization and Managed Care, 8 ANNALS HEALTH L. 275, 282 (1999).

${ }_{13}$ Luepke, supra note 12; see also National Labor Relations Act, 29 U.S.C. $\S \S 151-169$ (2000).

1429 U.S.C. § 157.

15 Powers, supra note 9 (citing these holdings as evidence of the NLRA's purpose of promoting "industrial stability" and "encouraging collective bargaining") (citations omitted).

${ }^{16}$ Id. (citing Am. Ship Bldg. Co. v. NLRB, 380 U.S. 300 (1965)).

17 Luepke, supra note 12, at 290. 
service of any family or person at his home, or any individual employed by his parent or spouse, or any individual having the status of an independent contractor, or any individual employed as a supervisor . . .."18

In squarely addressing such persons outside the definition of an "employee," the NLRA then goes on to define an independent contractor or professional employee as: (a) any employee engaged in work (i) predominantly intellectual and varied in character as opposed to routine mental, manual, mechanical, or physical work; (ii) involving the consistent exercise of discretion and judgment in its performance; (iii) of such a character that the output produced or the result accomplished cannot be standardized in relation to a given period of time; (iv) requiring knowledge of an advanced type ... ; or (b) any employee, who (i) has completed the courses of specialized intellectual instruction and study .... 19

As a result, only the fifteen percent of physicians who are employed by the government, hospitals, or HMOs and are not considered independent contractors or supervisors are classified as employees and covered under the NLRA. $^{20}$ The remaining eighty-five percent of physicians who practice solo or in private practice groups are considered independent contractors or "professional employees" and, consequently, do not qualify for the NLRA antitrust exemption. ${ }^{21}$ Furthermore, because these physicians are not protected by the antitrust exemption, any collaboration or joint activities are considered monopoly practices, price-fixing, and a restraint of trade, and will subject the physicians to criminal liability under the Sherman Act. ${ }^{22}$ Without the protection of the antitrust exemption, these physicians are placed in a Lilliputian position, exposed to the forces of the industry they live within and often times are overwhelmed by the sheer size and dominance of their opponents. ${ }^{23}$

1829 U.S.C. $\S 152(3)$.

19 Id. $\S 152(12)$.

20 Dionne Koller Fine, Exploitation of the Elite: A Case for Physician Unionization, 45 ST. LouIs U. L.J. 207, 214 (2001).

${ }^{21}$ Id.

${ }^{22}$ Luepke, supra note 12, at 290 (citing 15 U.S.C. $\S 1$ ).

${ }^{23}$ See SwIFT, supra note 1, at pt I. At another point in his travels, Gulliver wakes up on a beach, only to find himself tied and bound to the ground. Unable to move, he notices an army of miniature, human-like creatures fastening and securing the ropes that bind him. These creatures represent the population and people of Lilliput. While individually the Lilliputians would prove no match for the strength of even Gulliver, as a singular unified force, the Lilliputians exhibit a power equal to that of any Brobdingnagian. Small in stature, their culture is sophisticated and progressive. Their influence is only diminished by their size and the difficulties it poses in addressing the larger and overwhelming forces of the world. 


\section{INTRODUCING THE BROBDINGNAG-HMO TO THE LILLIPUTIAN- PHYSICIAN}

The introduction of HMOs has dramatically altered the landscape of the health care industry, as well as the way the nation approaches health care. The customary practice prior to the development of HMOs consisted of an environment lacking direct contracts between physicians and insurance companies. This meant that consumers paid for the services physicians provided according to their market-determined value. There was no middle man, insurance companies did not play a managerial role within the physician-patient relationship, and preventive care was not prevalent. ${ }^{24}$ In this age-old time where a medical service was a more direct, face-to-face, transparent business transaction, patients were acquired by word of mouth, and no cost-saving incentives existed to prevent a physician from offering as many medical services as necessary to address the patient's needs and ensure optimal health. ${ }^{25}$

Over time, however, premium level health care began to demand premium prices. In an attempt to reduce the significantly increasing health care costs in the early 1970s, the government passed the Health Maintenance Organization Act of $1973 .{ }^{26}$ By definition, "managed care is 'a type of health care financing and delivery that seeks to contain costs through using administrative procedures and granting financial incentives ..." to physicians. ${ }^{27}$ It is clear that the government's introduction and encouragement of such a business into the health care industry reveals its primary motivation: the reduction of cost at any expense, including the improvement of quality. ${ }^{28}$

While a one-dimensional, corporate attitude may be appropriate in the commercial context when dealing with material goods, it is inappropriate and inadequate for a health care industry aimed at preserving the very existence of human life. HMOs can provide an effective means of constraining costs and improving the organization of how physicians provide health care to the public. However, the tendency and inherent danger is for HMOs, with their financial focus, to jeopardize the interests of patients and quality care where those interests threaten the financial bottom line. As a result, a multi-dimensional perspective that couples consideration of patient needs alongside a concern for financial maximization must be employed to balance the all interests involved, allowing each to counteract the other in order to prevent sacrificing either.

24 AmeriHealth Inc., 329 N.L.R.B. 870, 871 (1999).

25 Id. at 872.

${ }^{26}$ Health Maintenance Organization Act of 1973, Pub. L. No. 93-222, 87 Stat. 914 (codified as amended in scattered sections of 42 U.S.C.); see also Fine, supra note 20, at 210.

27 E. Douglas Baldridge, Jr., Physicians Versus Managed Care: Is It Time for Physician Unions?, 28 N. KY. L. REV. 65, 70 (2001) (quoting Health Choice of N.W. Mo., Inc., 60 Fed. Reg. 51808, 51813 (1995)).

28 Fine, supra note 20, at 210. 
Otherwise, the financial myopia that HMOs sometimes suffer will continue to transform the practice of medicine into the business of health care.

Present day physician practices and procedures are constrained by contractual obligations to HMOs. Where once absent, HMOs now play a managerial role within the physician-patient relationship and influence physicians by providing suggestions and opinions that are primarily based on financial concerns and without medical expertise. As of 1999, HMOs had captured thirtyfive percent of insured patients, and this trend was rapidly increasing, expanding not only the scope of the HMO, but also its power as well. ${ }^{29}$ Furthermore, the financial influence of an HMO has the ability to provide physicians with incentives that may be contrary to the natural practice of medicine, including "an incentive to acquire as many healthy patients as possible and see them as infrequently as possible" in order to quickly generate revenue and clientele. ${ }^{30}$

This business based incentive goes hand in hand with the business motivations and focus of an HMO but can run counter to the physician's primary objective of treating patients to obtain optimal health. In addition, a physician's acquisition of patients has changed from word of mouth to a reliance on the marketing efforts and salesmanship of HMOs to gain the business of local employers and their employees. ${ }^{31}$ As a result, the introduction of HMOs and their increasing interference with physician autonomy has left some physicians feeling like they have lost control of their practices. ${ }^{32}$

\section{A. Creating an Imbalance in Power Between the Brobdingnag-HMOs and Lilliputian-Physicians}

The presence and growing popularity of HMOs has created an imbalance in situations where a very few number of HMOs dominate a large number of the nation's insured population. "Changes in the health care industry have led to an increased concentration of health care plans, including more than 162 mergers . . " between 1989 and 1999..$^{33}$ Furthermore, congressional findings revealed that the number of Americans who receive their health care coverage from managed care plans increased ten fold between 1979 and $1999 .^{34}$ In particular instances, one or two HMOs may dominate a market to such a degree as to nearly constitute a monopoly itself. A report published by Interstudy in December of 1998 "showed that two managed care companies dominate[d] the

29 AmeriHealth Inc., 329 N.L.R.B. at 871.

30 Id. at 872.

31 Id.

32 Fine, supra note 20, at 211-13; see also Luepke, supra note 12, at 277 (noting a "rising degree of unrest" among physicians).

33 Quality Health Care Coalition Act of 1999: Hearing Before the Comm. on the Judiciary, 106th Cong. 10 (1999), available at http://commdocs.house.gov/committees/judiciary/hju62446.000/hju62446_0f.htm [hereinafter Quality Health Care Coalition Act].

34 Id. 
health insurance product market in the Philadelphia region."35 "Excluding traditional Medicare and Medicaid patients, these two companies control[ed] 76\% of the market[;]" the equivalent of 3.8 million people out of the 4.3 million population. ${ }^{36}$ Furthermore, the leading managed care company held a majority of this market all by itself, controlling $57 \%$ of the market share. ${ }^{37}$

The American Medical Association's ("AMA") study of competition in health insurance exposes the reality and scope of this problem. In Competition in Health Insurance: A Comprehensive Study of US Markets, the AMA evaluates the concentration of major U.S. metropolitan markets and the market share of individual insurers in those markets. ${ }^{38}$

The 2004 study analyzed ninety-two metropolitan areas and found that $93 \%$ of the metropolitan areas were highly concentrated. ${ }^{39}$ Furthermore, $95 \%$ of these metropolitan areas contain at least one insurer that has a market share of $30 \%$ or greater all by itself. ${ }^{40}$ Thirty-seven percent of these metropolitan areas have at least one insurer with a market share of $50 \%$ or greater, and $6 \%$ have at least one insurer that has a market share of $70 \%$ or greater. ${ }^{41}$

Where reliable metropolitan area data were unavailable, the study analyzed data at the state level. ${ }^{42}$ The study revealed even more disturbing results of domination in areas that are inherently less equipped, less diverse, and more susceptible to corporate control and monopolistic influences. Similar to the study of metropolitan areas, $93 \%$ of the states were deemed highly concentrated. ${ }^{43}$ Furthermore, in terms of market share by individual insurers, the study found that $88 \%$ of these state-level markets contained at least one insurer with a

35 Id. at 23.

${ }^{36} \mathrm{Id}$.

37 Id.

38 Am. Med. Ass'N Private Sector Advoc. Group, Am. MEd. Ass'N, 2004 UpdateCOMPETITION IN HEALTH InSURANCE: A COMPREHENSIVE STUdY OF U.S. MARKETS (2004)(on file with author) [hereinafter 2004 COMPETITION IN HEALTH INSURANCE] ("The study bases its analysis of competition on health insurer market shares and on the Herfindahl Hirshman Index." The Herfindahl Hirshman Index is "a mathematically derived index of market concentration" that the Federal Trade Commission and United States Department of Justice themselves rely on "as an important calculation in evaluating the impact of mergers on competition in a market."); see generally AM. MED. Ass'N PRIVATE SeCtOR AdVOC. GROUP, AM. MED. Ass'N, 2005 UPDATECOMPETITION IN HEALTH INSURANCE: A COMPREHENSIVE STUDY OF U.S. MARKETS passim (2005) available at $\mathrm{www}$.ama-assn.org/ama 1/pub/upload/mm/368/compstudy_52006.pdf (presenting the most updated data regarding the concentration of HMOs in the health insurance industry).

392004 COMPETITION IN HEALTH INSURANCE, supra note 38.

40 Id.

41 Id.

${ }^{42}$ Id. With the exception of two states, these were situations where state populations are sparse with below six million residents, making collection of solely metropolitan area data less realistic and accurate and making the collective state data the best available proxy for market conditions.

${ }^{43}$ Id. 
market share of $30 \%$ or greater. ${ }^{44}$ Even more alarming, over half of the statelevel markets contained a market insurer with a market share of $50 \%$ or greater. ${ }^{45}$ In addition, $26 \%$ of these state-level markets contain an insurer with an overwhelming market share of $70 \%$ or greater. ${ }^{46}$ As a result, in over half of these state-level markets, a monopolistic aura and Brobdingnagian presence exists through a single insurer.

These figures not only demonstrate the strong dominance a small number of HMOs can pose over a geographic area and its physicians but also reflect the unprecedented consolidation of the health insurance market during the 1990s. "Between 1995 and 2004, there were over 400 mergers involving health insurers and managed care organizations. ${ }^{, 47}$ Furthermore, some analysts believe that the health care industry is poised for another round of consolidation and another new wave of mergers is underway. ${ }^{48}$

\section{B. Is HMO Consolidation Operationally Effective or Monopolistically Substandard?}

While common sense may suggest that consolidation results in greater operational efficiencies through maximizing economies of scale and lowering costs, ${ }^{49}$ reality and ailing patients would argue differently. During these spurts of consolidation, health insurance premiums have risen dramatically without any expansion of benefits to patients and the insured. ${ }^{50}$ Meanwhile, many of the large national health insurers have posted high profits during times of economic slowdown, making shareholders and highly paid senior executives the primary beneficiaries of consolidation. ${ }^{51}$

HMOs commonly defend their position by asserting that ease of entry in the marketplace by smaller HMOs proves that large insurance companies do not

44 Id.

45 Id.

46 Id.

47 Donald J. Palmisano, Health Insurance Markets Out of Whack, PHYSICIAN's NEWS DIG., Mar. 2005, available at http://www.physiciansnews.com/commentary/305.html.

48 Id. (noting that an example of this new trend is " $[\mathrm{t}]$ he 2004 acquisition of WellPoint Health Networks, Inc., by Anthem, Inc.," which created "the largest health insurer in the country" and provides "coverage to 28 million Americans."). Also adding to the consolidation is UnitedHealth Group, another health insurance Brobdingnag, that "has acquired four insurance companies in the past year, adding nearly four million covered lives, bringing its total to 22 million." Id.

49 Mark L. Glassman, Can HMOs Wield Market Power? Assessing Antitrust Liability in the Imperfect Market for Health Care Financing, 46 AM. U. L. REv. 91, 107 (1996); see also Ron Winslow \& Leslie Scism, Aetna Agrees to Acquire U.S. Healthcare; Pact for \$8.9 Billion in Cash and Stock will Create Leader in Managed Care, WALL ST. J., Apr. 2, 1996, at A2 (reporting that acquisition will result in the creation of a managed health care company serving twenty-three million people).

\footnotetext{
${ }^{50}$ Palmisano, supra note 47.

51 Id.
} 
dominate the market in a significant way. The truth is that "[e]ntry into health insurance markets is difficult." This is reflected by the minimal new entries into health insurance markets during times of high profits, which is precisely the time when new entries would be expected to peak. ${ }^{53}$ Furthermore, large insurers like HMO-WellPoint and HMO-UnitedHealth Group are choosing to acquire existing HMOs in markets instead of developing their own networks, which not only constitutes evidence of, but also helps to establish, the substantial barriers to market entry. ${ }^{54}$ Indeed, even if market entry was easy, difficulty still exists in sustaining a presence in the market when the whims of an insurance giant include exerting its Brobdingnagian force and monetary power to acquire and eliminate smaller competition.

More importantly, these circumstances result in a lack of competition in the health care industry. It is this lack of competition that has contributed to, if not created, one-sided conditions where HMOs have unchecked and unbalanced power in relation to the physicians. As a result, HMOs consistently force physicians into contracts exhibiting two main types of problems: (1) unfair reimbursement rates and (2) reduced physician control over medical decisionmaking. ${ }^{55}$ These "unfair reimbursement rates unjustly harm doctors in the short term" "56 and "also harm patients in the long-term by reducing access to quality health care." $"$ In some instances, unfair reimbursement rates have driven talented physicians out of a service area and experienced physicians into retirement. ${ }^{58}$ Meanwhile, the physicians who willingly endure the unfair conditions have the additional burden of having their practices constrained by a maze of HMO procedures and requirements that influence and indirectly dictate medical decision-making. ${ }^{59}$ While the HMOs' direct intention is typically to cut costs and save money, in reality it creates poor, restrictive working conditions for physicians and erodes the quality of patient care. ${ }^{60}$

52 Id.

53 Id. (explaining that in its challenge to the Aetna/Prudential merger, the DOJ noted that "effective new entry for an HMO or HMO/POS plan in Houston or Dallas typically takes two to three years and costs approximately $\$ 50$ million").

54 Id.

55 Quality Health Care Coalition Act, supra note 33, at 24.

56 Id.

57 Id.

58 See id. at 24-25. HMO dominance in dictating contract terms with physicians led one physician in Pennsylvania's thirteenth congressional district to ask, "[W] hy should I put up with unfair treatment and dropping reimbursement rates when I can move across the Delaware River to New Jersey, and set up a health practice?" $I d$. at 25 . This move would allow the physician to make thirty to fifty percent more revenue providing the same services. Id.

59 Id. at 24.

60 Id. 


\section{Double Standards in Evaluating HMO and Physician Antitrust Violations}

The Federal Trade Commission ("FTC") and the Department of Justice ("DOJ") have acknowledged the dramatic changes in the health care market. ${ }^{61}$ In response, they have published joint guidelines that advise insurance companies how to avoid antitrust liability. ${ }^{62}$ Enforcement of these guidelines, however, has been very relaxed. ${ }^{63}$ Indeed, DOJ attorney Mark Botti was only able to think of "one instance where the federal agencies have challenged a health insurer merger." 64

By contrast, physicians have faced higher scrutiny. Indeed, in April of 2002, the FTC expressly declared an intention to "find and bring cases against physicians" for antitrust violations. ${ }^{65}$ Between April 2002 and December 2004, when the FTC brought twenty-one complaints against physicians, twenty decided to settle rather than incur the wrath of the FTC and face exploitation during a long financial legal battle. ${ }^{66}$

Such dominance not only violates a sense of fairness and equality among parties in the health care industry but also promotes a monopolistic aura. This dominance is a sign that HMOs lack sufficient competition to be held in check and lends itself to abusive and unfair practices, including the aforementioned reimbursement rates that are driven so low as to threaten the ability of physicians and hospitals to maintain quality patient care.

\section{The Plight of the Powerless Physician Amidst the HMO's Monopolistic Authority}

Ironically, this lack of competition, consumer choice, and the HMO's unfettered control over establishing price are the very reasons physicians are prevented from jointly negotiating with HMOs. Antitrust arguments against

61 See Glassman, supra note 49, at 147 n.90 (referencing the United States Department of Justice and Federal Trade Commission's 1996 Statements of Antitrust Enforcement Policy in Health Care) (observing that "health care markets have continued to evolve in response to consumer demand and competition in the marketplace").

62 Glassman, supra note 49, at 147 n.91 ("Although the DOJ \& FTC guidelines do not directly address the activities of HMOs, Statement 9 of the Enforcement Policy" does indicate such an intention by establishing analytical principles relating to multiprovider networks. "This Statement establishes principles for review of arrangements that closely resemble and deal directly with HMOs, to be used to determine compliance with antitrust laws.") (citation omitted).

${ }^{63} I d$. at $147 \mathrm{n} .92$ ("[R] eporting that [the] DOJ and FTC gave antitrust clearance to 19 of 23 business arrangements addressed since adoption of [the] Joint Enforcement Policy. The FTC cleared nine of 13 deals among providers it reviewed, and the DOJ cleared all 10 of the deals it reviewed.") (citation omitted).

64 Palmisano, supra note 47.

${ }^{65}$ Id.

66 Id. 
physicians are based on the fear that groups of physicians will significantly influence prices and consumer access. These same practices currently exist with HMOs. The fear of providing physicians with too much power has led to disregard the true reality that HMOs have a monopolistic force in the health care industry.

This leads to hypocrisy because HMOs are permitted to dominate markets, having a near monopoly effect, while physicians are prevented from even negotiating as a cohesive group. In order for these physicians to effectively exercise their right to practice their profession in an autonomous manner, physicians must occupy a position of bargaining power equal to that of HMOs. Therefore, in markets such as Pennsylvania, where one or two HMOs substantially dominate the insured population, ${ }^{67}$ physicians should have the right to bargain collectively with HMOs to ensure equal bargaining power and to protect their right to practice their profession.

The words of Samuel Broder, the former director of the National Cancer Institute, not only articulate the feelings of physicians but also pronounce the importance of allowing both patients and physicians to retain a serious degree of control over the health care process: "[i]f it was up to the [National Institute of Health] to cure polio through a centrally directed program instead of an independent investigator driven discovery, you'd have the best iron lung in the world, but not a polio vaccine., ${ }^{, 68}$ Broder's words illustrate the importance of having multiple parties with varying interests address a situation. A system that only favors one side can only hope to temper a problem with half-solutions. The HMO's primary focus on cost containment prevents it from effectively addressing quality of care and patient needs as compared with a process that allows the insight and perspective of an invested and intimately involved physician. By allowing multiple parties to have a say in the situation, their divergent interests ensure that a comprehensive solution will be reached, addressing any potential shortcomings. Conversely, allowing a one-sided, detached party, such as an HMO, to deal with the problem alone will certainly result in significant short-comings where the physicians' and patients' interests have not been adequately represented. In this instance, the absence of a physician or patient voice to counter the HMO could result in a lower quality of patient care.

${ }^{67}$ Quality Health Care Coalition Act, supra note 33, at 23.

68 Samuel Broder, Wanted: Random Quotes That Don't Suck Too Much, Wonderful, Lovely Quotes, AMBROSIA SOFTWARE WEB BD., available at http://www.ambrosiasw.com/forums/index.php?s=9931 c4a9f462f3920a277e83c9f22f84\&showtopic $=105714 \& \mathrm{st}=0 \& \mathrm{p}=1600$ 044\&\#entry1600044. 


\section{UNIFYING LILLIPUTIAN-LIKE PHYSICIANS AND RESTRAINING BROBDINGNAG-LIKE HMOS}

\section{A. An Overview of Legislative Solutions Attempted by States}

Numerous states and even the federal government have recognized the eroding ability of physicians to exercise a proper degree of autonomy over their professional practice. As a result, a variety of solutions have been suggested and attempted over the past few years, ranging from state statutes granting physicians the right to bargain collectively with HMOs to alternative legislative approaches, including Any Willing Provider statutes ("AWP statutes").

While much is unknown about the consequences of change in the health care industry, it is certain that HMOs occupy an unchecked and unchallenged seat of authority. As a result, both physicians' and patients' rights are not properly heard or accounted for. Legislation has attempted to solve this problem but has thus far been unsuccessful on the physicians' front. Legislative attempts to magnify the effect and voice of physicians have been weak and underutilized. Many states have feigned their attempt to address the issue through the guise of AWP statutes, which fail to promote the physician's voice and secure legal rights that are moot in today's marketplace.

\section{B. Congress' Attempted Solution: The Quality Health Care Coalition Act}

\section{History of the Quality Act}

The federal government attempted to effectively address the plight of physicians in 2000 through the Quality Health Care Coalition Act of 1999 ("Quality Act"). ${ }^{69}$ The Quality Act offered to create an exemption to the federal antitrust laws and allow independent physicians to join together in negotiating with health plans in their geographical areas. ${ }^{70}$ The Quality Act was originally introduced by then House Representatives Tom Campbell (Republican of California) and John Conyers (Democrat of Michigan) in 1999. ${ }^{71}$ The Quality Act was approved by the House of Representatives on June 30, 2000 by a vote of 276 to 136 . $^{72}$ Despite strong bipartisan support, Representative Campbell's choice to leave the House in an unsuccessful bid for a senate seat robbed the Quality Act of its main sponsor, and it died in the U.S. Senate for lack of a sponsor. $^{73}$

71 Christopher Guadagnino, Fate of Joint Negotiation Legislation, PHYSICIAN's NEWS DiG., Mar. 2001, available at http://www.physiciansnews.com/cover/301.html.

72 Id.

73 Id. 
Congressional opponents of the Quality Act expressed concerns that "it did not offer a clear regulatory framework for oversight of negotiations," as well as fears that it would contribute to rising health care costs through possible higher physician compensation rates. ${ }^{74}$ In particular, the common cry of higher health care costs stymies and muffles any debate on the issue. These cries are often used in conjunction with sympathetic, anecdotal stories of high costs thrust upon the elderly and violations of the American "right" to health care. While these are serious concerns, over-emotional and dramatic tactics like these have blocked open-minded discussion of the issue. The Quality Act attempted to challenge these assumptions.

\section{Aims of the Quality Act}

The primary focus of the Quality Act was not to ensure higher compensation for physicians. Refusing to deny physicians' rights in an attempt to control patient health care costs, the Quality Act addressed all parties involved in the health care fiasco and sought to secure a fair and equitable process of providing health care. Incidentally, the supporters of the Quality Act argue that by providing physicians with a voice in the negotiating process, the quality of patient care will increase and the health care costs will be properly valued by the marketplace. Fears of exorbitant or distorted costs alone cannot control the provision of health care, and professional and personal rights cannot be sacrificed for wishful hearts that want cheap health care for all. Such action ignores the reality of the situation, undervalues the premium degree of health care in this country, and confounds our deepest and most traditional sense of personal freedom in our democratic, capitalist society.

Furthermore, quality and fees are inextricably related. Time is money. Services are money. In a capitalist society, everything is money, and everything is valuable. An attempt to constrain costs, is, by definition, an attempt to constrain quality patient care. To blindly focus on securing cheap prices and allow detached corporate businessmen to dictate how to constrain costs and cut resources would be a giant mistake of Brobdingnagian proportions. Cheap prices reflect low quality from low cost services. Health care services have defined values that can be measured by the marketplace, and any cutting of costs beyond the appropriate value of a service is no longer the elimination of wasteful spending, but rather is the voluntary and inane wielding of a scalpel upon necessary and useful aspects of health care.

From the obscure and distorted side line viewpoint, it is not easily known whether the businessmen are making smart decisions that enhance and improve the quality and provision of care. However, given that the fundamental maxim of any business is to maximize profit, a financially focused and money driven businessman will choose to sacrifice a higher quality of care for a lower quality 
of care if he can do so without losing business. In contrast, a directly interested and enabled physician, with interests more closely aligned with the patient, would serve as a better mechanism to voice patient demands, fight for the highest quality of patient care, and argue against harmful cost constraints that promise HMOs money while denying patients the hope of health.

\section{State Antitrust Exemptions for Lilliputian-like Physicians}

\section{Specific State Legislative Enactments}

States have enacted legislation explicitly giving physicians the authority to bargain collectively or negotiate with HMOs. The Texas statute, a model example of this type of legislation, is one of the more comprehensive efforts to address this issue, with numerous other states proposing similar legislation with minor differences. ${ }^{75}$ Texas Senate Bill 1468 allows physicians to jointly negotiate with health plans on compensation grounds so long as the health plan in question is deemed by the attorney general to hold a significant market share. ${ }^{76}$ Unfortunately, "the complexity of the rules . . . coupled with the tediousness and cost of the application to request to bargain with the health plan, led to a rarely utilized process ...." and no impact. ${ }^{77}$ Furthermore, a sunset clause contained in the statute terminated its effectiveness on September $1,2003 .^{78}$

Similarly, Alaska Senate Bill 256 allows for joint negotiations over feebased contractual provisions if a health plan or HMO is found to have substantial market power. ${ }^{79}$ California Senate Bill 2007 presumes "all third-party payers [of HMOs] in the state have significant market power" and, therefore, allows collective bargaining for physicians and requires HMOs to finance any costs the state incurs to institute collective bargaining by physicians. ${ }^{80}$ Florida

75 See 2000 Legislation: Physician Collective Bargaining Initiatives: Department of State Government Relations November 30, 2000, AM. NURSES Ass'N NURSING WORLD, available at http://www.nursingworld.org/gova/state/2000/phyco.htm; see also Fred J. Hellinger \& Gary J. Young, An Analysis of Physician Antitrust Exemption Legislation: Adjusting the Balance of Power, 286 J. AM. MED. Ass'N 83, 83 (2001) (stating that in 2000, Congress, eighteen state legislatures, and the District of Columbia introduced legislation that would grant physicians an antitrust exemption).

${ }^{76}$ See V. Denise Rose, Comment \& Note, The Texas Collective Bargaining Statute: Giving a Toothless Statute Some Bite, 4 Hous. J. HEALTH L. \& Pol'Y 87, 99 (2003).

77 Id. at 90-91; see also id. at 115 n.20 ("As of April 2001, only two physician groups had submitted applications to the Attorney General's office to 'collectively negotiate."').

${ }^{78}$ Id. at 91.

79 See Senator Pete Kelly, Alaska State legislature, Frequently Asked QUESTIONS - CSSB 256 (RLS): PHYSICIAN NEGOTIATIONS WITH HEALTH INSURERS (2000), available at $\mathrm{http} / / / \mathrm{www}$.akrepublicans.org/pastlegs/faqsb25604192000.htm.

${ }^{80}$ Newsletters: State Legislative Update, NAT'L Ass'N OF HEALTH UNDERWRITERS, Mar. 20-24, 2000, available at http://lobby.la.psu.edu/010_Insuring_the_Uninsured/Organizational_Statements/NAHU/NAHU_032000.htm. 
House Bill 1589 provides for collective bargaining over certain contract provisions, while other states, including Rhode Island House Bill 7952 and West Virginia House Bill 4604, allowed for collective bargaining or negotiations under specific conditions laid out in legislation. ${ }^{81}$

\section{Preemption Problems in Granting Physicians Antitrust Exemption Status}

In order to be effective, the state legislation must survive preemption challenges that would render it unconstitutional. Where federal law and state law conflict, the Supremacy Clause of the United States Constitution declares that federal law preempts the field and overrules any conflicting state law. ${ }^{82}$ Therefore, a state law allowing physicians to bargain collectively with HMOs will be held unconstitutional as against federal law, in direct conflict with the Sherman Act, and, consequently, will not survive a preemption challenge.

In order for such state laws to be upheld and enforceable, they must fall under the state action doctrine, a common law doctrine established in various prior Supreme Court cases. ${ }^{83}$ In Lafayette v. Louisiana Power \& Light Co., the Court stated that in order for conduct to qualify for immunity under the state action doctrine, it must satisfy a two-prong test: (1) the conduct must be pursuant to a clearly articulated state policy, and (2) the policy must be actively supervised by the state. ${ }^{84}$ This test was aimed at striking the balance between allowing the states to maintain freedom to administer state regulatory policies free of threat from antitrust laws and preventing purely parochial interests from disrupting the United State's free market goals. ${ }^{85}$

\section{Avoiding Preemption Problems and Ensuring Antitrust Exemption Status} for Physicians by Satisfying the State Action Doctrine

The first prong of this test requires the state to "clearly articulate" the state policy that is behind the statute. A "clearly articulated" state policy may be derived from or implied by the language of the legislation. ${ }^{86}$ While the clearly articulated prong does not require the language to be expressly stated in the statute, the state interest must not be as neutral and vague as in the Supreme Court

81 Newsletters: State Legislative Update, NAT'L Ass'N OF HEALTHUNDERWRITERS, Mar. 13-17, 2000, available at $\mathrm{http}: / /$ lobby.la.psu.edu/010_Insuring_the_Uninsured/OrganizationalStatements/NAHU/NAHU_031300.htm.

${ }^{82}$ U.S. CoNST. art. VI, $\S 2$.

83 See generally Bates v. State Bar of Ariz., 433 U.S. 350 (1977) (upholding the state action doctrine); see also Goldfarb v. Va. State Bar, 421 U.S. 773 (1975) (addressing the aspects of the state action doctrine).

${ }_{84}$ Lafayette v. La. Power \& Light Co., 435 U.S. 389, 410 (1978).

${ }^{85}$ Id. at 415-16.

86 Id. at 410. 
case of Community Communications Co. v. Boulder. ${ }^{87}$ In Boulder, a statute granting general authority to govern local affairs was held as failing to clearly articulate when the state's position regarding regulation of local cable television was found to be one of neutrality. ${ }^{88}$ In Boulder, the Court stated that the statute must show " that the legislature contemplated the kind of action complained of." "89 While it is impossible to predict and explicitly state all consequences of a statute, the Court will not allow states to grant dictator-like governing powers without some sense of direction or evidence of contemplation.

The second prong of the state action test is whether there is "active supervision" by the state of the regulated conduct. This requirement primarily serves the evidentiary function of ensuring that the actor is engaging in the challenged conduct pursuant to state policy. ${ }^{90}$ A determination of "active supervision" requires an examination of the state's knowledge of the conduct based on its monitoring and its integral role in supervising, facilitating, and even, to some extent, controlling the process.

The Texas application process for state supervised collective bargaining "requires a copy of contracts with health plans with whom negotiations will take place, income data pertinent to the negotiations, and a set of fees to pay the attorney general's administrative costs."91 Such burdensome administrative requirements may make completion of the application a one month process ${ }^{92}$ but clearly errs on the side of evidencing active state supervision.

The Supreme Court has yet to address any of the existing state laws and whether they fall under the protection of the state action doctrine; however, it is important to note that the test is designed to acknowledge legitimate state interests and allow states to responsibly and sovereignly govern such issues as long as states do not impede on the national scheme. If the Court's position on AWP statutes is any indication of how much latitude the Court will afford the state in drafting legislation, then states will have the power to enact statutes that are broad in scope, applicable to all or most licensed providers in the state. ${ }^{93}$ Regardless, states must intentionally draft and word their statutes to reflect a narrow, defined intent to govern physician collective bargaining with HMOs in order to protect public health and welfare.

${ }^{87}$ Cmty. Commc'ns Co. v. Boulder, 455 U.S. 40, 56 (1982).

88 Id.

89 Id. at 55.

90 Lafayette, 435 U.S. at 427.

91 Guadagnino, supra note 71.

92 Id.

93 See Gene A. Blumenreich, United States Supreme Court Upholds "Any Willing Provider" Statutes, 71 AM. Ass'N OF NURSE ANESTHETISTS J., 259, 259 (2003), available at $\mathrm{http} / /$ www.aana.com/uploadedFiles/Resources/Legal_Briefs/2003/p259-262.pdf. These laws sought to protect both physicians who might otherwise be excluded from participating in the HMO plan due to the HMOs' bias, as well as to ensure that patients would not lose their freedom to choose their physicians nor have that freedom of choice be restrained by the HMOs' choice of which physicians with whom the patients may contract. Id. 


\section{AWP Statutes as a Popular Alternative Solution to Empowering Lilliputian-like Physicians}

\section{AWP Statutes Defined}

States have also attempted to combat the weak position of physicians through alternative legislative means. AWP statutes require HMOs to permit any physician or health care provider located within the geographically covered area to participate in the HMO plans, so long as the physician is willing to meet the terms and conditions the HMO demands of the other physicians. ${ }^{94}$ These statutes attempt to provide physicians with power by ensuring them access to any and all HMO plans they may wish to join. Ensuring access to a one-sided marketplace, however, does nothing to address its inherent inequity. If anything, it secures and exploits the power of HMOs by subjecting a greater number of physicians to their Brobdingnagian authority. For states interested in restoring control and autonomy of a physician's practice to the physician, such legislation is a misguided attempt and, as time has shown, is generally a moot point.

\section{The McCarran-Ferguson Exception}

The McCarran-Ferguson Act "made an exception to the antitrust laws for conduct regulated by a state as "the business of insurance." 95 As with many legal issues, this vague phrase required further definition. The Court in Group Life and Health Insurance Co. v. Royal Drug Co. recognized a distinction between the regulation of "insurers" and the regulation of "insurance" and held "that third-party provider arrangements between insurers and pharmacies were not the business of "insurance.",96 Determining whether the relationship between insurers and physicians was the regulation of "insurers" or "insurance" would determine whether AWP state statutes were constitutional or unconstitutional as preempted by federal law.

This question was addressed by the Court in the case of Kentucky Ass'n of Health Plans, Inc. v. Miller. ${ }^{97}$ The Court upheld the statute, stating that AWP statutes "regulated insurance by imposing conditions on the right to engage in the business of insurance. A statute that imposed conditions on the right to be an insurer regulated the [general] 'business of insurance ....'"' and not specific insurers. ${ }^{98}$ Therefore, AWP statutes fall under the McCarran-Ferguson exception to federal regulation and antitrust law.

94 Id.

95 Id. at 260.

96 Group Life \& Health Ins. Co. v. Royal Drug Co., 440 U.S. 205, 210 (1979).

97 Ky. Ass'n of Health Plans, Inc. v. Miller, 538 U.S. 329, passim (2003).

98 Blumenreich, supra note 93 , at 261. 
Insurance companies are likely to be dissatisfied with this result and view the outcome as frustrating their efforts to guarantee volume to current, specific provider physicians who charge insurance companies lower prices in exchange. ${ }^{99}$ In the absence of AWP statutes, HMOs can contract with a limited number of physician providers based on a set number of criteria, a practice known as selective contracting. By limiting the number of providers, HMOs can reduce overall administrative costs and negotiate lower rates by offering a higher per-physician case load. ${ }^{100}$

It is possible, however, that AWP statutes simply change the mechanism for ensuring low prices for insurance companies. Where two friendly parties once conspired to trade volume for low prices, now the marketplace, with its increased number of physicians and relatively equal demand, will provide insurance companies with comparable low prices and the same upper hand in contracting with physicians. Indeed, many states have been hesitant to enact AWP statutes, finding them unnecessary. Because employer groups are free to choose insurance companies, insurers must strive to ensure customer satisfaction in a competitive market. As a result, having a large provider network is in the interest of the insurance companies, making such legislation a moot point.

Not only do these statutes fail to alter the financially dominant position of the HMOs but also are a failed and compromised alternative for the simple reason that their primary purpose does not address the problem: the unequal distribution of power between physicians and HMOs. While protection from discrimination secures inclusion, it does not secure equality for all of those inside that protected arena. Statutes must be concerned with and focused on creating an equality of bargaining power or an avenue to such a position. Forfeiting or ignoring this element of equality fails to address the main problem and leaves the health care landscape, and future, unchanged.

Securing an individual physician's right to be included in the HMO is a serious issue, particularly considering that physicians are becoming increasingly dependant on HMOs as a source of income. ${ }^{101}$ Such dependency becomes a problem when the general power of a physician to negotiate and bargain with an HMO remains absent. Misguidedly, AWP statutes address the individual physician and not the ability of all physicians to unify and present a united front to counter the powerhouse position of HMOs.

\section{AWP Statutes Prove to be an Inadequate Solution to Empowering} Physicians

While the outcome of Kentucky Ass 'n ensures that qualified, willing providers will not be pushed out of the marketplace by the preferential

$\begin{array}{rl}99 & I d . \\ 100 & \text { See id. } \\ 101 & \text { Id. }\end{array}$ 
whims and fickle admittance gates of insurance companies, these statutes do nothing to strengthen the position of these physicians in negotiations with the insurance companies. Rather, the statutes only ensure that all physicians will have fair access to compete with one another within the realm of the HMO. A redistribution of volume, shifting the gross number of insureds that visit one physician to another, or simply splitting a finite number of insureds among a larger number of physicians does not strengthen the position of physicians. This does not ensure physicians proper compensation or autonomy; it only prevents discrimination.

\section{DWARFIng The BRoBdingnag AND MAGNIFYING THE VoICE OF THE LILLIPUTIAN}

\section{A. Proposed Legislation to Enlarge the Influence of the Lilliputian-like Physicians and Counterbalance the Giant Power of Geographically Dominant HMOs}

Specific legislation must be developed and implemented to effectively secure the rights of physicians and counterbalance the monopolistic authority of an HMO that dominates the business of a particular geographic region. This Note proposes that physicians should be authorized to jointly negotiate with health plans in situations in which a small number of health plans substantially dominates a geographically covered market area, as determined by either a statistical determination or the attorney general's judgment. ${ }^{102}$ The grounds for this type of legislation exist within both established case law and employment principles that recognize the need to address unequal positions of bargaining power. Furthermore, in order to ensure the effectiveness of this legislation, states must not impose cumbersome requirements that strangle any attempt to utilize such legislation. Rather, states can phrase and shape this legislation to ensure adequate oversight to satisfy state action doctrine concerns without rendering the legislation ineffective.

\section{B. A Recent NLRB Decision Laid the Foundation for Granting Physicians the Authority to Bargain Collectively in Specific Circumstances}

This proposal upholds traditional legal principles, while also addressing new and current demands that changing times have created. While the general rule that physicians are not exempt from antitrust statutes still applies, the uncontemplated, modern face of health care does justify carving out a small, but

102 See 2004 COMPETITION IN HEALTH Insurance, supra note 38. The Herfindahl Hirshman Index could be used to derive an appropriate and meaningful statistical determination. The FTC and DOJ rely on the Herfindahl Hirshman Index as an important calculation in evaluating the existence or absence of competition in markets, as well as identifying monopolistic presences or where a small number of companies substantially dominate a geographic area. 
appropriate, exception.

The judiciary has only commented on the relationship between independent physicians and HMOs once before, and then only through the voice of a regulatory board. ${ }^{103}$ In AmeriHealth Inc. \& United Food \& Commercial Workers Union, Local 56, $A F L-C I O$, the petitioning physicians were attempting to form a proposed bargaining unit to represent the interests of physicians employed by AmeriHealth in Atlantic and Cape May Counties of New Jersey. ${ }^{104}$ This bargaining unit would present a unified front in voicing the interests and demands of physicians employed by AmeriHealth during contract negotiations with the corporate powerhouse, AmeriHealth.

The NLRB ruled to dismiss the "petition on the ground that the petitioned-for physicians are independent contractors" and not de facto "employees," which would have given the physicians the right to bargain collectively with AmeriHealth. ${ }^{105}$ Indeed, while the NLRB in AmeriHealth ruled that certain factors did not amount to considering physicians as de facto employees of health plans, the Board's language in balancing the factors and considering the physician's employee argument indicates that certain circumstances could arise where such a de facto status would be recognized and the right of physicians to bargain collectively could exist. ${ }^{106}$

\section{Identifying the Specific Circumstances that would Authorize Lilliputian- like Physicians to Bargain Collectively with Dominant HMOs}

The NLRB in AmeriHealth followed the precedent of the Supreme Court and applied the common law of agency to determine whether the particular physicians involved constituted "employees" or "independent contractors."107 This common law analysis, phrased in the words "servant" and "master" respectively, examines the following factors:

(a) the extent of control which, by the agreement, the master may exercise over the details of the work;

(b) whether or not the one employed is engaged in a distinct occupation or business;

(c) the kind of occupation, with reference to whether, in the locality, the work is usually done under the direction of the employer or by a specialist without supervision;

(d) the skill required in the particular occupation;

(e) whether the employer or the workman supplies the

${ }^{103}$ AmeriHealth Inc., 329 N.L.R.B. 870, passim (1999) (addressing the claim of 652 physicians in October of 1999).

\footnotetext{
${ }^{104} I d$. at 870.

$105 \mathrm{Id}$.

106 Id. at $884-85$.

107 Id. at 882.
} 
instrumentalities, tools, and the place of work for the person doing the work;

(f) the length of time for which the person is employed;

(g) the method of payment, whether by the time or by the job;

(h) whether or not the work is a part of the regular business of the employer;

(i) whether or not the parties believe they are creating the relation of master and servant; and

(j) whether the principal is or is not [in] business. ${ }^{108}$

While all factors are relevant and none is singularly dispositive, the NLRB's analysis focused heavily on the control exerted by the employer over the "employee." Relying heavily on the theory that servants have a very close economic relation with their employers and are subject to their employers' control, the NLRB suggested that factor (a), the "control factor," may be most indicative of a judicial ruling. ${ }^{109}$

The NLRB stated that a primary legal issue at stake was to determine "whether the physicians, in their work for AmeriHealth, [were] so integrated with and controlled by AmeriHealth that they [met] the statutory definition of employees ... [or] servants." 110 As a result, the NLRB requested an investigation into the amount of control and the intimacy of the relationship between the physicians and AmeriHealth. ${ }^{111}$ The investigation revealed that AmeriHealth did control, or had the right to control, many details of the services physicians deliver to AmeriHealth members, including whom a physician is required to treat. ${ }^{112}$ AmeriHealth also imposed personal standards on physicians, "such as the maximum number of patients a physician may see in an hour, the size of the patient waiting room and the maximum amount of time a patient may be kept waiting there." 113 In addition, AmeriHealth employed on-site visits, credentialing, and status standards to monitor physicians and ensure they were living up to AmeriHealth's standards. ${ }^{114}$ If the physicians failed to perform to AmeriHealth's specific standards, AmeriHealth had the right to terminate the contract. $^{115}$ This exhibits a strong degree of authority and control in the

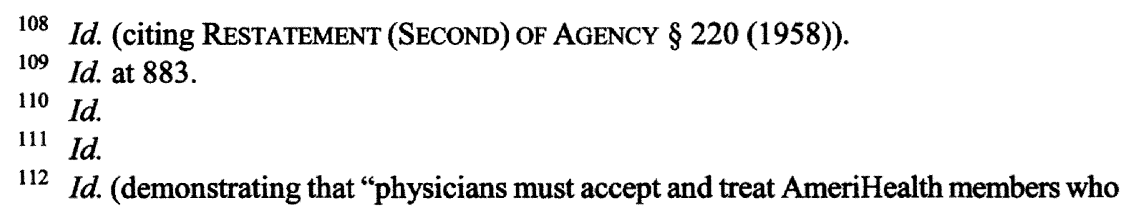
select the physicians or are referred to them," and that this arrangement continues indefinitely until either AmeriHealth terminates the arrangement or the physician overcomes his fear of losing patients and chooses to terminate the arrangement).

$\begin{array}{ll}113 & I d . \\ 114 & I d . \\ 115 & I d .\end{array}$ 
relationship, causing the significant "control factor" of the common law of agency test to weigh in favor of servant status. ${ }^{116}$ While the NLRB acknowledges that this oversight is not extensively exercised by AmeriHealth, it also acknowledges that the "control factor" of the common law agency test examines a master's right to control, not his actual exercise of control. ${ }^{117}$

In speaking to both factors (a) and (c) of the common law of agency test, the NLRB commented on the lack of oversight performed by AmeriHealth and noted that physicians are not required to practice under the actual eye of a supervisor. ${ }^{118}$ The NLRB did state, however, that being a "servant" does not require an individual to be physically under the control of another. ${ }^{119}$ Rather, "[m]any servants perform exacting work requiring intelligence rather than muscle." 120 Therefore, while acknowledging that AmeriHealth is not physically controlling the physicians, the NLRB is recognizing the structure of the relationship and the intangible degree of control AmeriHealth exercises over the physicians.

The NLRB continued its focus on the "control factor" by noting that "[m]any, if not most procedures performed by the physicians currently require no precertification" or pre-approval from AmeriHealth. ${ }^{121}$ The intangible aspect of the situation, however, reveals AmeriHealth's true control over the physicians. While AmeriHealth may not actually require physicians to obtain permission for the majority of their activities and procedures, a physician's decision-making process may be severely influenced and constrained by the various financial incentives, procedural standards, and blatant expectations AmeriHealth has enforced through its contract.

The alternative options available to the physicians may have been most decisive in the Board's decision. Undermining the physicians' argument of intangible control, AmeriHealth's market share is less than ten percent of the insured population for its coverage area. ${ }^{122}$ In addition, the physicians were free to contract with other insurance companies. ${ }^{123}$ Even though a physician may risk losing HMO-AmeriHealth insured patients by contracting with other insurance companies, HMO-AmeriHealth's market share is not so dominant as to seriously jeopardize the physicians' access to other patients. Furthermore, the NLRB concluded that the physicians had a "meaningful opportunity" to negotiate the terms of compensation and standards with HMO-AmeriHealth, based on the fact that HMO-AmeriHealth has negotiated special rates with ten

116 See id.

117 Id.

$118 \mathrm{Id}$.

119 See id.

120 Id. (noting that officers of a corporation or a ship, interns at a hospital, and janitors performing manual labor are all considered servants).

121 Id. at 884 .

122 Id.

123 Id. 
percent of its physicians. ${ }^{124}$ In contrast, situations in which physicians are continually denied revised compensation rates and standards could indicate a lack of voice, unfair bargaining, and excessive control by the HMO.

Also weighing against a finding of excessive control by AmeriHealth over the physicians is the fact that the physicians practice medicine in their own name, not AmeriHealth's, and are highly skilled professionals with a high degree of autonomy over their practice. ${ }^{125}$ While that reasoning may have been valid in this particular situation, the NLRB and state legislatures must acknowledge that intellectual and individual professions are also subjected to the control and whims of larger, Brobdingnagian forces, especially in today's health care world where large HMOs contain costs by constraining physician practices. Indeed, the NLRB leaves open the possibility of finding servant status due to excessive and coercive intangible control in the physician-HMO relationship by issuing a narrow ruling specific to the facts of the case. ${ }^{126}$

Even though the NLRB rejected that the particular physicians were de facto employees, it indicated that a physician might be considered a de facto employee if the HMO's control is so excessive and prevalent as to dictate the actions of physicians. ${ }^{127}$ While this is a fact sensitive inquiry, such situations are more likely to occur where HMOs substantially dominate market share. These environments establish a fertile ground for excessive power for HMOs and foster a vulnerable position for powerless physicians.

The NLRB contrasts the position of the physicians with an illustration of a photographer who is employed by a newspaper to take pictures. ${ }^{128}$ Upon taking the pictures, the photographer is not allowed to sell his work to the employer's competitors and is therefore bound to the newspaper alone and completely subject to it. ${ }^{129}$ Instead, the NLRB sees the position of the physicians more like that of a freelance advertisement photographer who contracts with an advertising agency. ${ }^{130}$ Despite being monitored and supervised by art directors to achieve the agency's desired result, this photographer, as a highly skilled professional, is given autonomy over the technical means chosen to carry out the art director's instructions. ${ }^{131}$

If tweaked in one of two ways, however, this illustration could lead to a different conclusion. First, if the contract establishes the right and ability of the art director to substantially influence and control the photographer's autonomy, whether that right is exercised or not, then the photographer has essentially contracted himself into the position of a servant. Second, in a situation in which 
only one or two advertising agencies exist and substantially dominate the market, the freelance photographer's ability to operate his own business is significantly destroyed. The freelance photographer is then freelance in name only. $\mathrm{He}$ has no other advertising agency to offer his business. The reality of the situation is that he is just as dependent on the dominant, monopolistic advertising agency as the newspaper photographer.

Proposed state legislation should identify and articulate the circumstances that would give rise to such a de facto status and give physicians the right to jointly negotiate with health plans. Indeed, this is the very role of the legislature - to listen to the needs of its people and the demands of changing times and implement adequate regulation in response. Should the state improperly legislate, it is the role of the judiciary to clarify its position and judge the legislation improper. For the time being, however, the judiciary has left this area of law open to legislative action.

\section{Learning from the Mistakes of Prior Legislative Attempts and Effectively Crafting the Proposed Legislation}

\section{Ensuring Adequate State Oversight and Satisfaction of the State Action Doctrine}

Five years after the onslaught of pro-physician legislation, states now have the opportunity to learn from the mistakes and pitfalls of prior legislative attempts. Nowhere is this more true than in the realm of adequate state oversight, as required under the state action doctrine. In their attempts to secure adequate oversight to ensure the constitutionality of the legislation under the state action doctrine, states have employed requirements that have strangled the process and choked-off any potential power to physicians. Two common flaws have plagued past legislation: (1) the length of the application review process, and (2) the role of the government, specifically the attorney general, in conducting the negotiations between physicians and HMOs.

A lengthy application review process only results in significant delays, sometimes spanning years, and discourages physicians from participating in the process. ${ }^{132}$ A brief time period must be established in order to secure not only the practicality and effectiveness of the process but also to communicate strong support for the physicians and patients who are directly affected by the contracts HMOs form with physicians in the geographic area.

In addition, states must secure the validity of the process of collective bargaining itself by keeping it within constitutional constraints. Prior legislation made the mistake of requiring the state attorney general to serve as the oversee-

132 See Rose, supra note 76, at 105-06 (noting that the " 'expensive and time-consuming application' process" in Texas renders it ineffective, as well as the risk that insurance companies may refuse to bargain after physicians are approved). 
ing authority of negotiations in order to avoid antitrust law violations and satisfy state oversight qualifications for the state action doctrine. Antitrust law and oversight concerns, however, do not require that a governmental third-party be present to facilitate, mediate, or arbitrate every negotiation. ${ }^{133}$ Instead, the actual requirement is that a governmental third-party be the intermediary between the two bargaining parties. ${ }^{134}$ Alternatively, this requirement can be adequately fulfilled by disclosing information and the details of the bargaining meetings. Examples of avenues for such disclosure include the initial application, filing requirements of negotiation activities and minutes, and establishing a proper complaint procedure for HMOs that believe negotiations are occurring contrary to the statute.

\section{Focus on Collective Bargaining, not Arbitration}

Some advocates of pro-physician legislation suggest arbitration as an effective means of securing physician rights and demands in the health care industry. ${ }^{135}$ In this scenario, an arbitrator would be free to select between the physician group's proposed solution or demand, and leave the current HMO regulation or fee in place. ${ }^{136}$ While an arbitrator would certainly bring the parties to the table and promise some definitive resolution to the issue, this type of legislation does not address the key concern presented by the situation: the physician's lack of voice and bargaining power. ${ }^{137}$ Furthermore, the dimension of finality involved in the arbitration process, as opposed to collective bargaining, may force physicians to significantly compromise their demands for fear of HMOs denying their solutions in the all-or-nothing atmosphere of arbitration. Such a process will fail to secure the rights of physicians to voice their strongest demands directly at the feet of HMOs. Rather, such legislation is a harness on the physicians' attempt to truly demand solutions and changes from HMOs.

Further, state and federal legislation must be aimed at ensuring a fair and equitable process for determining procedures and contracts in the health care industry and nothing more. For example, HMOs should still be capable of utilizing their strengths in conducting negotiations. Such legislation should not place the rights of a physician above the HMO and attempt to find binding ways to ensure health care reform. Rather, it is more important, valuable, and appropriate that legislation focus on securing an equitable forum of discussion where all parties are represented and their demands are heard. This forum is

133 Id. at 111.

134 Id.

135 Id.

136 Id.

137 See id. Advocates of arbitration note that the dimension of finality involved in arbitration would make it unlikely for physicians to propose unreasonable demands on HMOs. As a result, physicians are likely to propose only reasonable and realistic solutions that HMOs are willing to consider, increasing the chances of the parties coming to a consensus. Id. at 112 . 
responsible for securing just and fair results, not government legislation, and this understanding must not be compromised. An attempt to radically secure the rights of physicians may result in nothing more than a shift of monopolistic power from one side to the other. The provision of a balanced and more equal bargaining environment, however, fosters a solution that will address shortcoming and concerns of all parties involved.

\section{Require Good Faith Bargaining from HMOs}

Under federal law, collective bargaining typically requires communication and negotiations between the employer and employee. ${ }^{138}$ An employer's refusal to meet with employee groups at reasonable times or to discuss mandatory or crucial issues of concern is considered unfair labor practice. ${ }^{139}$ Logically, HMOs should be bound by this same duty. The focus, however, must be on the good faith efforts of the HMO to bargain with physician groups. It is important that the duty of the HMO be couched in the principle of good faith and not an explicit requirement to sit down at the negotiating table as some pro-physician advocates would suggest. An express, mandatory requirement on attendance at bargaining sessions not only falls short of the desired outcome but also creates an even more hostile and dramatic environment by pitting two unwilling sides against each another.

In contrast, a focus on requiring HMOs to conduct collective bargaining in good faith would foster a positive atmosphere for communication and also provide broader legal grounds for ensuring HMOs' participation in the bargaining process. Narrow and express mandatory provisions leave room for loop holes that can be exploited by creativity. For example, a requirement of mandatory attendance at bargaining negotiations does not expressly state what company employee must be present. For example, HMOs could possibly satisfy such a hostile requirement simply by sending the CEO's secretary. On the other hand, however, it is unrealistic to require the company president to attend every bargaining meeting, particularly when multiple meetings may be occurring in multiple locations at the same time. Therefore, extending a good faith bargaining requirement to HMOs would allow courts to properly consider the context and facts of a situation in determining whether physicians are being denied their right to voice demands and solutions, whereas narrow and strict requirements only encourage HMOs to find ways to escape the bargaining process.

\section{E. Predicted Impacts from Implementing the Proposed Legislation}

The primary results of this legislation would affect three main issues: (1) 
competition in the health care industry, (2) quality of patient care, and (3) health care costs. The implementation of this type of legislation has the potential to improve the quality of patient care and maintain current health care costs while increasing competition in the health care industry. The following subparts examine the arguments and assumptions that underlie these issues.

\section{Increased Competition and Justice for Physicians through a Balanced Playing Field}

The proposed legislation will inject a healthy dose of competition into geographic areas in which HMOs face no competition from other HMOs and are able to subject physicians to meager reimbursement rates and dictate terms of patient care. America has relied on the concept of free market competition in the vast majority of the economy's markets. ${ }^{140}$ Indeed, the Sherman Antitrust Act was enacted to preserve competition in the free market and has been hailed the Magna Carta of free enterprise. ${ }^{141}$ Over the past century, the competition of the free market has driven innovation, provided choice, and lowered prices. ${ }^{142}$ Indeed, the economic vitality of the nation depends upon the competitive structure of a health care industry. ${ }^{143}$ Joel Klein, Assistant Attorney General for the Department of Justice, stated that the "ultimate goal is the preservation of competition at all levels of the health care industry."144

Rep. Tom Campbell, State House Representative for California, described the current lopsided, competitive structure of the health care industry by stating that "what we have today is muscle. And I have got muscle on my right arm, and I am trying to put muscle on my left."145 Giving physicians the muscle and a voice to counteract the powerhouse HMO position will result in a more equitable distribution of profits between the HMO and physician, create market penetration opportunities for smaller competing HMOs in regions where physician choice was prohibited before, and create more choices for patients through diversified physician-HMO relationships and market-encouraged innovation.

The most important result of such legislation, however, may be lost in all the data and theory. This legislation would support the principles of liberty and personal autonomy that are so deeply rooted in our nation's history and values. Whether regarding economics or public health, our courts have always been weary to tread on the personal liberty and freedom that was first established by the Constitution. Indeed, the free marketplace touts the success of the individual entrepreneur, and due process aims to protect people from anything short of

140 Quality Health Care Coalition Act, supra note 33, at 70.

141 Id.

142 Id.

143 Id. (stating that in 1997 the "annual revenues of health care professionals covered by the Sherman Act ranged between $\$ 300-400$ billion, about 4-5\% of GDP").

144 Id. at 73.

145 Id. at 109. 
necessary government regulation. The current situation allowing HMOs to exercise such dominance and authority over physicians cannot be reconciled with a devotion to these principles. No matter what the monetary savings, compromising these principles is far more costly and unacceptable.

If fear exists among HMOs that allowing physicians to have a voice in the practice of their profession will result in higher costs to consumers, then legislatures must provide consumers with a voice and thereby seat all three affected parties at the table. The answer is to invite, not exclude, more voices and more parties to the table. The omission of such voices, including that of the physicians, is a compromise that cuts corners and results in an inadequate and unjust result, similar to how HMOs compromise quality of patient care and the right of physicians to exercise full autonomy in their practices in order to reach the desired result of lower costs and higher profits. The answer to consumer fears is to allow for inclusion in the process and to secure a forum for discussion that will facilitate the most honest and equitable result. Physician rights that are continually denied and limited, however, will confine the industry to its current imbalance and inadequacies.

Some measures have been taken, such as consumer directed health plans ("CDHPs") and a Patient Bill of Rights, to give consumers a seat at the table; however, these efforts are incomplete as long as they are not coupled with this type of proposed legislation. "CDHPs rely upon consumer decision support tools, including extensive use of data comparing providers, to influence consumer relationships with providers." ${ }^{\text {"146 }}$ These plans attempt to give consumers control over their health care insurance money and provide adequate information about physicians, HMOs, and medical services to enable them to make informed decisions on how to spend this insurance money. ${ }^{147}$ Such plans attempt to make consumers their own advocates and allow physicians and HMOs to compete in a free market for their business. Indeed, the emergence of CDHPs gives consumers a voice and power to counteract HMOs. Meanwhile, a Patient Bill of Rights would establish a list of explicit rights that provide grounds for patient claims and an avenue for judicial attention. While such solutions may strengthen the role of the consumer, such activism by itself does not address the injustice burdening physicians and actually works to further weaken their position and voice. Physicians would then be the sole party excluded from exerting an influence in the provision of health care in America.

146 Edward F. Shay, Physician Impacts of Consumer-Directed Health Plans, PHYSICIAN'S News DiG., Jan. 2006, available at http://www.physiciansnews.com/business/106shay.html.

${ }_{147}$ See id. ("CDHPs typically describe a benefit scheme with the following characteristics. First dollar coverage under a health benefits policy with generous benefits is replaced with a combination of a health savings account and a high-deductible catastrophic benefits policy, often geared to selected provider networks. The health savings account is akin to a medical IRA. It offers tax advantaged, self-managed funding for health care up to about $\$ 5,500$ annually."). 


\section{The Impact on Health Care Costs and Subsequent Economic Conse- quences}

The primary criticism of this legislation is that it would raise costs and encourage the very problem that HMOs were established to address. ${ }^{148}$ Opponents claim that higher fees for professional services would be passed onto consumers and result in higher prices for health insurance coverage. ${ }^{149}$ This assertion is based on the assumption that HMOs will choose to pass on increased costs in the form of higher prices for health care insurance. This is not a mandatory result of allowing physicians to negotiate with HMOs, and to the extent it is a likely result, it is merely a reflection of the primary motivating factor of HMOs: monetary profit. While such legislation may lead to a redistribution of profits, with the HMOs retaining less and the physicians receiving more, the HMO will still make a degree of profit. ${ }^{150}$ Indeed, this is certain because it would be against the interest of the physicians to negotiate for such a high amount of compensation that would cause the HMO to go out of business. Physicians need HMOs, just as HMOs need physicians. Therefore, the real issue is whether the HMO chooses to recapture the redistributed profits by charging consumers higher prices. ${ }^{151}$ Some believe HMOs will undoubtedly choose to recapture lost profits by passing the costs onto the consumers and patients. Even this claim, however, acknowledges the abusive degree of power HMOs currently hold. Essentially, this argument asserts that HMOs are parties with unfettered market power that will use that power as any rational businessperson would to make money. ${ }^{152}$

This emphasizes the HMOs' primary objective of making a profit, whether at the expense of the consumer or by cutting the quality of health care. ${ }^{153}$ This self-interested motivation and perspective is the very characteristic that is attributed to physicians and that critics of this type of legislation say prevents physicians from fairly negotiating with HMOs. If the HMO's primary objective was to cut costs to the consumer, as touted by the press and industry, profit would not dictate its decisions; rather, costs would. Therefore, an HMO should be operating as a nonprofit entity and not a profit-seeking, consumer-gouging entity. While it is unlikely this conversion will take place, the introduction of physicians to the negotiating table would counter this coercive force.

The best method of cost constraint is not a one-party dictatorship; it is a competitive marketplace with competing interests that forces innovation, creates choice, and lowers prices. ${ }^{154}$ This is the basic economic lesson that encour-

See Quality Health Care Coalition Act, supra note 33, at 77.

151 Id.

152 See id.

153 Id. at 27.

${ }^{154}$ Id. at 70 . 
ages low costs in every other American industry. The initiation and preservation of competition in the health care industry is the key to limiting costs and begins by allowing a second party, the physicians, the voice to counter the Brobdingnagian presence of HMOs.

Finally, while it may not be pleasant for HMOs or consumers, any result in increased costs would not be due to physician greed but rather due to the honest valuation of the procedure by the marketplace. America provides health care options that are among the best in the world and simply were not available even decades ago. ${ }^{155}$ Paramount health care at a low cost simply is not the reality. It reflects a mismatch of expectations in the minds of the average American. ${ }^{156}$ Requiring world-class procedures at discount rates is costing physicians their practices and robbing regions of their doctors. It is not fair for one party to carry this burden. It should be redistributed among all parties involved, especially the Brobdingnag-like HMO.

\section{An Improved Quality of Patient Care}

The primary objective of a physician is to treat and heal patients with a compassionate nature and a respect for human dignity and rights. ${ }^{157}$ As a stockdriven, profit-seeking corporation, the primary objective of an $\mathrm{HMO}$ is to make money ${ }^{158}$ In fact, the HMO business paradigm is to make up for lower costs by directing a higher volume of patients to the same number of doctors. ${ }^{159}$ "This business model intrinsically sacrifices personal attention to patients and puts quality of care in jeopardy." ${ }^{160}$ As a result, HMOs are less than ideal advocates for patients and increased quality of care. The role of the physician is much more closely linked to the interests of the patient and makes for a more effective patient advocate.

The financial structures of many HMOs are not driven by patient need. If an $\mathrm{HMO}$ is not providing a service because it is not as profitable as an alternative or it takes up time and money when a physician could be seeing another patient, the HMO is sacrificing the quality of treatment to make a profit. ${ }^{161}$ Physicians are rewarded for seeing more patients in less time and providing fewer services. It must be recognized that "fees and quality are inextricably related."162 By allowing physicians to negotiate for performance based compensation, as opposed to volume based compensation, compensation will be

155 Id. at 89.

156 Id.

157 Am. Med. Ass'n, Principles of Medical Ethics, http://www.ama-assn.org/ama/pub/category/2512.html (last visited Apr. 13, 2007) (adopted June 17, 2001).

158 Quality Health Care Coalition Act, supra note 33, at 27.

159 Id. at 26.

160 Id.

161 Id.

162 Id. at 139. 
directly linked to patient needs and care. Not only will physicians be able to negotiate for better financially structured relationships but also will be able to influence the appropriate standards of care. In contrast, HMOs currently choose to employ some industry standards but often create their own standards and specific expectations of a physician's practice. This practice of HMOcreated standards and the influence it exerts on a physician's practice could threaten the quality of care patients receive by rooting the standard of physician care in the HMO's corporate objectives, as opposed to the patient's needs or physician's opinion. Furthermore, such decreased quality of care may not be actionable under medical malpractice statutes if the decline is pervasive throughout the industry, as is entirely possible with the dominant and omnipresent influence of HMOs. Given that medical malpractice claims rooted in negligence are largely based on a physician's adherence to the customary standard of care, a comprehensive decline in the quality of care would simply represent a new, lower industry standard of care. More important than industry standards or negligence claims, however, is that this echoes the fundamental and continual problem of how Brobdingnag-like HMOs have the power to bully the practices and lives of Lilliputian-like physicians.

\section{CONCLUSION}

This Note, in Part II, examined the history of an employee's right to collectively bargain with employers, as well as a physician's right to collectively bargain with HMOs. Part III addressed the changing landscape of health care in the United States, and Part IV examined attempts taken by various states, doctors, and the federal government to address the needs of powerless physicians against HMOs. Finally, in Part V, this Note proposed a solution that would properly extend physician rights and empower physicians to seek fair and equitable arrangements with HMOs wherever a Brobdingnag-like HMO structure is found.

Through consolidations and a blindingly narrow focus on constraining costs, the current state of the health care industry places physicians in a Lilliputian-like position. Small and voiceless, physicians are simply outmatched by the sheer dominance and force asserted by Brobdingnagian HMOs. Unlike in Gulliver's Travels, however, these two contrasting populations live in the same world. As a result, legislation is necessary to facilitate communication and cooperation among these diverse cultures with their divergent interests. Furthermore, such legislation would secure an improved quality of care for the patients who are indirectly affected by the feuding civilizations. A failure to address this situation may result in the extinction of the independent physician practice as it currently exists.

Where an HMO substantially dominates a geographic market, physicians are subject to the force and size of the HMO, resulting not only in unfair rates and arrangements, but also an inequitable process that denies physicians the voice and right to make adequate and professional demands. Rooted in princi- 
ples of autonomy and freedom, and expressly against monopolies and restrained trade, the legal system must respond. Physicians deserve and demand legislation that will secure an equitable and open forum for negotiation and contract formation. Furthermore, a forum of this nature would recognize and validate the self-evident rights of physicians to voice their opinions against corporate powerhouses and also strive to advocate on behalf of the patient's absent voice for increased quality care. As a result, it is imperative that states acknowledge the wayward inequity allowed by current law and remedy it through legislation. Such legislation should identify geographic regions in which HMOs exhibit a monopolistic authority and then empower physicians with an equal authority to unite and bargain collectively with the Brobdingnagian HMOs. 